\title{
ANALISIS FAKTOR - FAKTOR YANG MEMPENGARUHI \\ LOYALITAS PELANGGAN TERHADAP PEMBELIAN ANAKAN MURAI BATU PRESTASI ( STUDI KASUS PADA AZIS BIRDFAM DI BOYOLALI TAHUN2020 )
}

\author{
Muhammad Azis Rahmanto ${ }^{1)}$, Dasmadi ${ }^{2}$, dan A. Fidhdiarr Ariestanto TNK $^{3}$ \\ Program Studi Manajemen \\ Fakultas Ekonomi \\ Universitas Boyolali \\ Jl. Pandanaran 405, Telp. 0276321328 Boyolali \\ e-mail: azisrahmanto435@gmail.com, dasmadi82@gmail.com, kafidiar@yahoo.com
}

\begin{abstract}
ABSTRAK
Penelitian ini bertujuan untuk mengetahui adanya pengaruh produk, harga, kualitas pelayanan Azis Birdfam di Boyolali.Teknik pengumpulan data menggunakan wawancara, kuesioner dan studi dokumen yang dilakukan pada bulan mei tahun 2020 sampai juli tahun 2020.

Teknik pengambilan sampel yang digunakan berdasarkan bertepatan, semua sampel data telah dianalisis dari analisis regresi linier berganda memperoleh nilai adjusted $\mathrm{R}$ Square sebesar 4,9\% variabel produk, harga, kualitas pelayanan berdampak pada loyalitas pelanggan sedangkan selisihnya 95,1 \% berdampak oleh variabel lain seperti ikatan emosional, kepercayaan, kemudahan, kepuasan pelanggan dan pengalaman dengan perusahaan.

Hasil pengkajian ini merumuskan bahwa produk, harga dan kualitas pelayanan menggunakan uji secara parsial memiliki dampak berdasarkan relevan terhadap loyalitas pelanggan pada Azis Birdfam di Boyolali.
\end{abstract}

Kata Kunci : Produk, harga, kualitas pelayanan, loyalitas pelanggan.

\section{ABSTRACT}

This study aims to determine the effect of product, price, service quality of Azis Birdfam in Boyolali. The data collection techniques used interviews, questionnaires and document studies conducted in May 2020 to July 2020.

The sampling technique used was coincidental, all data samples were analyzed from multiple linear regression analysis to obtain an adjusted $R$ Square value of $4.9 \%$. product variables, price, service quality have an impact on customer loyalty, while the $95.1 \%$ difference has an impact on other variables such as emotional ties, trust, convenience, customer satisfaction and experience with the company.

The results of this study formulate that the product, price and service quality using a partial test has an impact based on relevance to customer loyalty to Azis Birdfam in Boyolali.

Keywords: Product, price, service quality, customer loyalty. 


\section{Pendahuluan}

Budidaya burung berkicau merupakan salah satu hobi masyarakat Indonesia. Burung kicau atau burung hias disenangi karena perawatan tidak memerlukan lahan yang luas dan tidak mengakibatkan pencemaran lingkungan. Burung berkicau juga bisa menghasilkan suara yang indah sehingga bisa menjadi hiburan bagi masyarakat. Punahnya vegetasi menyebabkan juga punahnya sumber pakan bagi burung ( Firdaus, Setiawan dan Rustiati ( $2014: 26$ ). Rawan yang diakibatkan oleh menurunnya kualitas lingkungan dan hilangnya habitat.

Ternak burung murai Azis Birdfam dari bakalan menjadi burung siap kontes dengan menuai hasil yang maksimal hingga juara di berbagai event kontes burung seperti bnr, ebodjaya, radja wali, independen teknologi pemasaran seperti burung cililin,burung conin, burung tengkek buto, burung kenari, burung lovebird yang dapat ditirukan burung murai batu bakalan saat beranjak dewasa dan ikut disertakan di event perlombaan hingga mendapat gelar juara dan sudah mencakup wilayah soloraya,burung murai azis birdfam sudah mendapat predikat juara serta piala dan piagam bergengsi yang sudah mendapat pengakuan dari Komunitas Murai Batu Soloraya (KMBS). "Dalam sektor bisnis di pasar Burung karyawan mempunyai andil yang sangat penting karena bertepatan meningkatnya intensitas persaingan dan jumlah pesaing menuntut perusahaan untuk selalu memperhatikan kebutuhan dan keinginan pelanggan serta selalu berusaha mencukupi harapan pelanggan dengan cara memberikan pelayanan yang lebih menyenangkan".

Sehingga pada latar belakang diatas maka dapat dirumuskan permasalahan faktor harga, produk dan kualitas pelayanan berpengaruh secara parsial dan simultan terhadap loyalitas pelanggan menggunakan tujuan penelitiannya adalah faktor harga, produk dan kualitas pelayanan berpengaruh secara parsial dan simultan terhadap loyalitas pelanggan dan Manfaat yang diharapkan dari penelitian ini Penulis/mahasiswa Hasil penelitian dapat menambahkan keterampilan dan kesiapan penulis bila nantinya masuk ke dunia kerja dan memperluas pengetahuan terutama yang berkaitan dengan produk ( X1 ), harga ( X2 ) dan kualitas pelayanan ( X3 ) dengan Loyalitas Konsumen ( Y ). Bagi Pengusaha Penelitian ini diminta bisa memberikan informasi sebagai bahan pengarahan dan pertimbangan dalam upaya meningkatkan loyalitas konsumen. Berlandaskan uraian diatas maka pengkajian ini "ANALISIS FAKTOR - FAKTOR YANG MEMPENGARUHI LOYALITAS PELANGGAN TERHADAP PEMBELIAN ANAKAN MURAI BATU PRESTASI ( Studi Kasus Pada Azis Birdfam di Boyolali tahun 2020)

\section{Landasan Teori dan Pengembangan Hipotesis}

\subsection{Bauran Pemasaran}

Menurut Tjiptono ( 2014 : 41 ) Bauran Pemasaran (marketing mix) adalah selengkap fasilitas yang digunakan pemasar untuk membentuk karakteristik jasa yang ditawarkan pelanggan. Kelemahan - kelemahan memotivasi banyak ahli pemasaran untuk mendeskripsikan ulang bauran pemasaran sedemikian rupa sehingga lebih aplikatif untuk sektor jasa. Keputusan perihal setiap unsur bauran pemasaran saling berkaitan satu sama lain. Meskipun demikian tingkat kepentingan yang ditekankan pada masing - masing unsur cenderung bervariasi antar jasa.

\subsection{Kualitas Produk}

Menurut Kotler dan Armstrong ( 2014 : 253 ) "Product quality is the characteristic of a product or service that bear on its ability to satisfy stated or 16 implied customer needs" yang bila diartikan dalam Bahasa Indonesia: kualitas produk adalah karakter yang dimiliki sebuah produk yang mempunyai kemampuan untuk memenuhi kebutuhan pelanggan. kualitas adalah unsur yang saling berhubungan yang berdampak pada kinerja dalam memenuhi harapan pelanggan. 
Kualitas tidak hanya memusatkan pada hasil akhir yaitu produk dan jasa tetapi menyangkut kualitas manusia, kualitas proses dan kualitas lingkungan. Dalam mewujudkan suatu produk dan jasa yang berkualitas melalui manusia dan proses yang berkualitas.

2.3 Harga

Menurut Alma (2011 : 169) harga adalah dasar finansial atau ukuran lainnya termasuk barang dan jasa yang ditukarkan agar memperoleh hak kepemilikan atau penggunaan suatu barang dan jasa sehingga memicu kepuasan konsumen. Menurut Assauri (2014 : 223) harga adalah unsur yang menciptakan penghasilan penjualan sedangkan unsur lainnya hanya unsur biaya saja. Berdasarkan kesimpulannya harga adalah beberapa uang yang ditanggung jawabkan atas suatu produk yang ditukar konsumen atas nama baik yang dimiliki produk tersebut

2.4 Kualitas Pelayanan

Nasution dalam Rusydi (2017 : 39) kualitas pelayanan adalah tahap keutamaan yang diharapkan dan penanggulangan atas tingkat reputasi tersebut untuk memenuhi konsumen. kualitas pelayanan sebagai sifat dari penampilan produk atau kinerja merupakan bagian utama dari strategi perusahaan dalam meraih keunggulan yang berkesinambungan.

2.5 Loyalitas Pelanggan

kepuasan yang dikemukakan oleh Kotler dalam buku karangan Rambat Lupiyoadi ( 2014 : 228 ) merupakan tahap perasaan di mana konsumen menyatakan hasil perpaduan atas kapasitas produk jasa yang diterima dengan yang diharapkan. Loyalitas merupakan sesuatu yang timbul tanpa adanya paksaan tetapi timbul dengan sendirinya.

2.6 Penelitian Terdahulu

1. 2017 mengkaji kualitas pelayanan dan loyalitas pelanggan Hasil pengkajian menunjukan bahwa variabel kualitas pelayanan mempunyai dampak yang signifikan terhadap loyalitas pelanggan Sama - sama menggunakan uji coba validasi dan analisis regresi”.

2. 2019 mengkaji kualitas pelayanan berdampak positif dan signifikan terhadap kepuasan konsumen. Ini menunjukkan bahwa semakin baik perbaikan kualitas pelayanan yang dilakukan di Pasar Depok Solo maka konsumen akan merasa puas. Sama-sama menggunakan uji coba validasi dan analisis regresi”.

3. 2017 mengkaji bahwa kualitas produk dan harga berdampak positif terhadap kepuasan pelanggan dengan menggunakan Sama - sama menggunakan uji validasi dan analisis regresi".

\section{Metode Penelitian}

Penelitian ini menggunakan penelitian kuantitatif yakni yang datanya berupa bilangan dan analisis menggunakan statistik. Data diperoleh dari perusahaan berupa data yang dapat dihitung atau angka yang diterima dari dokumen atau informasi dan data yang diterima dari hasil survei berupa informasi yang dikumpulkan dari responden menggunakan kuesioner. Teknik pengumpulan data menggunakan metode yang stategis digunakan oleh peneliti yang bertujuan untuk mendapatkan data dalam penelitian ada beraneka ragam metode pengumpulan data yang dapat dilakukan dalam sebuah penelitian diantaranya wawancara, observasi, angket (kuesioner) dan studi 
dokumen. Populasi merupakan sekumpulan dari orang atas kejadian atau sesuatu yang menjadi perhatian bagi peneliti untuk diteliti ( Sekaran 2010-266 ). Paguyuban dalam penelitian ini adalah semua pelanggan burung murai Azis Birdfam di Boyolali”.

"Sampel menurut sugiyono ( 2010 : 62 ) merupakan bagian dari jumlah dan karakteristik yang dimiliki oleh populasi”. "Sampel adalah sekelompok populasi yang terpilih untuk berpartisipasi dalam penelitian (Malhorta, 2009 : 364 )". Dalam penelitian ini, peneliti menetapkan keputusan pembelian sebagai variabel terikat ( $\mathrm{Y}$ ), variabel Terikat adalah variabel yang berpengaruh yang menjadi akibat karena adanya variabel bebas ( Sugiyono, 2001: 30 ). Keputusan pembelian tidak terpisahkan dari bagaimana sifat seorang konsumen sehingga masing-masing konsumen memiliki kebiasaan yang berbeda dalam melakukan pembelian. "Variabel bebas adalah variabel yang berdampak atau yang menjadi sebab perubahan timbulnya variabel Dependen ( Sugiyono, 2001 : 33 )". Analisis Deskriptif yaitu suatu penjabaran untuk memaparkan variabel produk, harga dan kualitas pelayanan terhadap loyalitas pelanggan anakan murai batu Azis Birdfam di Boyolali. Analisis Regresi Berganda yaitu suatu penjabaran untuk melihat sejauh mana berdampak variabel produk, harga dan kualitas pelayanan terhadap loyalitas pelanggan anakan murai batu Azis Birdfam di Boyolali.

\section{Hasil dan Pembahasan}

Hasil analisis data menghasilkan nilai - nilai yang digunakan untuk membuktikan hipotesis dari penelitian yaitu sebagai berikut :

\subsection{Uji $F$ terhadap loyalitas ternak anakan murai batu prestasi}

Berdasarkan hasil analisis regresi berganda dengan uji F bahwa Sig. 0,022 < 0,05 berarti bahwa semua variabel berpengaruh secara simultan terhadap loyalitas pelanggan Azis Birdfam di Boyolali.

\subsection{Uji t terhadap loyalitas ternak anakan murai batu prestasi}

Hasil Uji t Pembahasan :

1. Berdasarkan hasil analisis regresi berganda dengan uji t bahwa produk, apabila sig. 0,013 > 0,05 maka perihal ini membuktikan bahwa variabel produk secara parsial mempengaruhi signifikan terhadap loyalitas pelanggan Azis Birdfam di Boyolali..

2. Berdasarkan hasil analisis regresi berganda dengan uji t bahwa harga, apabila sig. 0,047 > 0,05 maka perihal ini membuktikan bahwa variabel harga secara parsial mempengaruhi signifikan terhadap loyalitas pelanggan Azis Birdfam di Boyolali..

3. Berdasarkan hasil analisis regresi berganda dengan uji t bahwa kualitas pelayanan, apabila sig. 0,547>0,05 maka perihal ini membuktikan bahwa variabel kualitas pelayanan secara parsial tidak mempengaruhi signifikan terhadap loyalitas pelanggan Azis Birdfam di Boyolali. 


\section{Kesimpulan}

1. Berdasarkan hasil analisis regresi berganda dengan uji $\mathrm{F}$ bahwa sig. $0,022<0,05$ berarti bahwa semua variabel mempengaruhi secara simultan terhadap loyalitas pelanggan Azis Birdfam di Boyolali.

2. Berdasarkan hasil analisis regresi berganda dengan uji t bahwa produk, jika sig. $0,013>0,05$ maka perihal ini menunjukkan bahwa variabel produk secara parsial tidak mempengaruhi signifikan terhadap loyalitas pelanggan Azis Birdfam di Boyolali.

3. Berdasarkan hasil analisis regresi berganda dengan uji t bahwa harga, apabila sig. $0,047>0,05$ maka perihal ini membuktikan bahwa variabel harga secara parsial mempengaruhi signifikan terhadap loyalitas pelanggan Azis Birdfam di Boyolali.

4. Berdasarkan hasil analisis regresi berganda dengan uji t bahwa kualitas pelayanan, jika sig. 0,547>0,05 maka perihal ini membuktikan bahwa variabel kualitas pelayanan secara parsial tidak mempengaruhi signifikan terhadap loyalitas pelanggan Azis Birdfam di Boyolali. 


\section{DAFTAR PUSTAKA}

Azizah, A., \& Widyastuti, A. (2013). Hubungan Antara Kepuasan Konsumen Dengan Loyalitas Merek Pada Pengguna Kartu Prabayar Simpati. Jurnal Psikologi, 9 ( 1 ), 1 - 8.

Azwar, S. (2011). Reliabilitas dan Validitas cetakan pertama.

Basuni, S., Hernowo, J. B., \& Mulyono, M. (2005). Studi beberapa aspek ekologi burung murai batu di hutan wisata pananjung pangandaran. Media Konservasi, 10 ( 2 ).

Buchari, A.(2011) "Manajemen pemasaran dan pemasaran jasa. Bandung: Alfabeta".

Dharmmesta, B. S., \& Handoko, T. H. (2008). Manajemen pemasaran: analisis perilaku konsumen. Edisi Pertama, Cetakan Keempat, Penerbit BPFE, Yogyakarta.

Ferdinand, A. (2014). Metode Penelitian Manajemen: Penelitian Untuk Skripsi ( Doctoral dissertation, Tesis dan Disertasi IImu Manajemen, Edisi ke 5. Badan Penerbit Universitas Diponegoro. Semarang ).

Gerung, C. J., Sepang, J., \& Loindong, S. (2017). "Dampak Kualitas Produk, Harga dan Promosi Terhadap Keputusan Pembelian Mobil Nissan X-Trail Pada PT. Wahana Wirawan Manado. Jurnal EMBA: Jurnal Riset Ekonomi, Manajemen, Bisnis dan Akuntansi, 5 ( 2 )".

Othman, L. ( 2012 ). ANALISIS HAMBATAN BERPINDAH (SWITCHING BARRIER ) KARTU PRABAYAR SIMPATI TELKOMSEL (STUDI PADA MAHASISWA FISIP UNIVERSITAS RIAU). Jurnal Aplikasi Bisnis, 1(1).

Parwati, I. (2019) "Dampak Kualitas Pelayanan Terhadap Loyalitas Pelanggan Dan Kepuasan Pelanggan Sebagai Variabel Mediasi Di Pasar Burung Depok Solo( Doctoral dissertation, Universitas Muhammadiyah Surakarta )".

Sugiyono. (2008) "Metode penelitian pendidikan:( pendekatan kuantitatif, kualitatif dan $R \& D)$ ). Alfabeta. 